\title{
Zoltán SZÚTS
}

\section{A Critical Approach to Digital Pedagogy - The Search for an Organic Methodology in the Information Society}

\section{Introduction}

In present, the use of info-communication technology has become a living communication reality that pervades everyday life. The relationship between the learning and teaching process to medialization and digital technology has become increasingly prominent. Since the spread of digital data, and especially the emergence of the World Wide Web, many phenomena and trends and could have been observed regarding the use of ICT in education. Some of these trends have reached on their peak the plateau of productivity since the 1990's, but more have proven to be merely fad. One of the most frequently used methods in the present is, for example, the flipped classroom, where students acquire the theory at home through digital curricula, while in the classroom they deepen their knowledge and interact with teachers. From the 2000s, e-learning has become a new educational environment which includes novel forms of learning and teaching supported by ICT, both in form, content, and methodology. In present, E-learning continues to be an important trend, and many teachers are just now discovering the benefits of the platform and some of them turn to blended learning (Kis-Tóth Lengyelné, 2012).

The use of a Learning Management Systems (LMS) relies on multimedia and linking texts - hypertext while requires interaction between the learner (user) and the text (information). Gamification supports the player within, where point systems, levels, and healthy competition between students play an important role. Although not a traditional methodology, the use of social media and web 2.0 in education is becoming more and more important, students follow or write blogs, or edit Wikipedia. As it is observed that nowadays students' attention can be maintained for a shorter period of time then in the case of previous generations, the use of micro-content in the transfer of knowledge adapts to the accelerated information-taking habits. In the universe of micro-content, the use of smaller curricula reinforces the popularity of independent learning. Finally, current trends include the strengthening of the interactive visual learning environment, (Benedek, 2019) and the use of augmented reality content, or how Microsoft refers to it, mixed reality.

The lesson of the past 30 years might be that using technology itself, without a complex methodology that takes into account as many didactic aspects is not enough. The technology-centered approach teaching-learning process is just as much a mistake as the thinking that automatically assumes the effectiveness of learning organization due to the use of modern technology. Any methodology in which the demonstration is given prominence describes that its application, if unrelated to the process, can very easily become a dead end. The use of technology, unless it is based on methodological principles, does not lead to an increase in the efficiency of the learning process. By focusing merely on the application of technology, unrealistic expectations cannot be met." (Ollé, 2013: 102.)

\section{Aim of the paper}

This paper represents an approach to digital pedagogy that complements previous educational approaches from the field of communication and media science. It is safe to assume that over the last three decades, after the emergence of the global digital network, it has first become a vital part of the learning process, and by today it has reached the end of the experimental phase. We have to develop a complex, holistic methodology theory and prove it in practice. Our previously published book on online communication and media, Online, discusses some of the theoretical issues of learning from the perspective of communication and media science. 
Our study states that, although we know a number of good practices, a unified methodology (later specialized in special the field of training, for example in vocational education) can only be developed if we take into consideration the well-established didactic rules that ensure the effectiveness of teaching and learning processes in the information society that exists in a constantly beta state. Although the technology: interfaces and standards are constantly changing - evolving - a methodology that critically approaches digital pedagogy should be based on both previously effective pedagogical practice and the rules of online communication.

We are in a transition period where old methods may not work just because of the digital divide. This divide is made up of several elements. One of its components is economic, as the cyclical purchase of high-end digital devices entails a substantial investment. The other component is a social one. It depends on the status in society and the position on the labor market, to which degree an individual lives in line with technology, and if one possesses the necessary knowledge to use it properly. Although the initial perception of the divide was based on generational distinctions, we believe that economic and social aspects should be taken into account instead of $\mathrm{X}, \mathrm{Y}$ and $\mathrm{Z}$ generalization.

There are several questions to be addressed. Does the seemingly endless offer of content support personalized learning or does it enhance the mass production character? Does artificial intelligence help humans' cognitive development and individual learning paths, or does it drive humans out of the labor market and thus reduce the importance of acquiring knowledge? Is Big Data providing a useful pattern for improving the quality of education, or is it a tool for classification and surveillance? Does outsourced human memory make it easier for us to focus on the point or the lack of data reduces our creativity? If a person does not memorize the information, then how it combines knowledge and be creative? Will an e-learning training reduce drop-out rates or do those without digital devices and mentors get even further away from acquiring knowledge in the information society?

We are aware that it is impossible to put into practice an effective methodology without dipping the theoretical approach into practice (Duchon - Tóth, 2016), so this paper is a part of a bigger project. There is another paper to follow, that will provide the necessary empirical background.

\section{Digital pedagogy: a friend or a servant?}

The biggest change compared to the traditional classroom environment in digital pedagogical systems is that learning supported by electronic devices is independent of time and space and apparently aims to transform both student and teacher roles. As a result, the educational framework expands and blends with leisure time (Benedek, 2013), and it is already difficult to separate learning processes from work or mere information consumption. „We might understand this flexibility to reflect Bauman's 'liquid modernity' in which the boundaries between the study, work and leisure become thoroughly blurred" (Bauman, 2017).

The cornerstone of an effective methodology is a self-reflection ability to continually learn the nature, the implications, and the ways of thinking of the information society, and become familiar with its techniques. Even if institutionalized education really takes the principle of lifelong learning seriously, it will not be able to adapt itself to intensive use of technology according to the present rate of development (Ollé, 2013, 11.) The changes should come changes must come quickly; otherwise, there will be a gap between common and educational use of ICT (Molnár, 2016). By placing the digital transition of the educational environment at the center of our study, the changes in the methods of the new learning environment are brought to the fore (Racskó, 2017).

Due to the nature of the information age, students want to gain knowledge on a wider scale, while searching and processing digital curricula according to patterns of everyday user practice. Following the strategies offered by their teachers who grew up on printed textbooks, the students of today are no longer able to navigate online safely, they are not able to determine the relevance or credibility of information provided on a variety of websites. New communities are emerging around the learning process; websites and web 2.0 provide time and space-independent access to information and 
opportunities for individuals to become members of virtual study groups. At the same time, this explosion of information radically changes teachers' roles. Teachers (and textbooks) are no longer the only source of information. They are intended to provide methodological assistance to students in the form of a moderator, similar to one that dwells in online forums. This moderator role is already linked to the online environment, as moderators select the content of the forums and coordinate workflows. There has never been such a close connection between the online communities, collaborative workspaces, and the learning environments. Not only does the technology make a significant difference in storing information, but it also plays a major role in achieving unprecedented levels of accessibility, sharing, and interactivity, (i. e. crowdsourcing). The use of all of these also provides the students with enormous motivational power.

There has never been a case in history where an infrastructure development (a computer network) had such an impact on society. Among its indicators, we can easily grasp the impact of content creation, message delivery, the democratization of dialogue between different social agents, or even more active participation of citizens in the public domain.

Students spend an active amount of their free time in interactivities related to online communities, only a small percent of it is a learning activity. We have to assume that if students spend a significant amount of their free time online, not only do they learn in this environment, but they are also affected by different educational impact systems (Lévai, 2013, 90). At the institutional level, the issue of digital pedagogy is also emerging: In other words, the European Union has developed a Digital Competence Framework for Educators (DigCompEdu) in 2017 to help identify teacher training needs. ${ }^{1}$

\section{Information Society}

In order to develop a coherent methodology, we need to thoroughly explore and map the framework within which teaching and learning processes take place. In an information-based information society since the early 1990s, online communication has overcome the physical boundaries that air travel has begun to demolish in the industrial era. In digital literacy based on hypertext, a distance between nods is only a click away. All objects (texts, images, sounds, and videos), all the information is just a few clicks away, and it can be accessed through the network from anywhere in the physical world. Today this process is marked with the challenge if deciding which information is authentic or relevant, and which is fake and not useful.

In the new digital paradigm, data can now be transferred, shared, searched, copied or even faked online, while the technology is accessible to everyday users. Of great importance is the fact that the internet is decentralized as opposed to industrial communication systems. In addition, social media bypasses gatekeepers or at least pushes them further from the content. Due to the easily editable nature of online context, it allows users to become authors or content creators - prosumers. The structure of online media content is non-linear, with hyperlinks providing free passage of information, but the same time, digital content does not have a distinctive body as for example books, so the worth of it is often underrated (Szúts, 2018).

In the information society, digital technology, embedded in all stages of human life, simultaneously facilitates and complicates the learning-teaching process. The question is, does the seemingly endless supply of content support the development of personal learning paths? IT corporations today play a key role in the development of Artificial Intelligence, Big Data, smart devices, smart homes, and smart cities, and it is largely up to them to decide what type of applications will dominate everyday lives of citizens. But it also means that info-communication technology is getting cheaper and gaining prominence in everyday life and that more and more users are accessing it. Governments also have a crucial role to play, as although their own developments do not approach the corporate sector, they have a strong say in the application of technology.

\footnotetext{
${ }^{1}$ See: https://ec.europa.eu/jrc/en/digcompedu
} 
The question is whether artificial intelligence helps the individual's cognitive advance and supports the development of individual learning paths or, on the contrary, removes the weak students from the educational system. In a dystopia, artificial intelligence erases non-skilled workers from the labor market and replaces their work with algorithms. This reduces, for example, the importance of acquiring knowledge. The Big Data systems are useful when they show patterns that help improve the quality of education, but it can be a tool for selecting the weakest students and excluding them from the learning process. Human memory outsourced to digital storages makes it easy for individuals to focus on issues without having to memorize large amounts of information. In a negative scenario, in the absence of memorized data, human creativity diminishes because there is nothing to build on or combine with. Elearning can reduce drop-outs by removing barriers of time and spaces from education. But is it possible that those individuals without digital devices will be left without the help of teachers and mentors and thus move away from the labor market?

György Csepeli and Gergő Prazsák point out that "the role of memory is changing. The new culture, among other things, means we have to learn again how to search. There remains more space in our brain for thinking and creation. The use of the internet in society reaches a critical point when the network loses its technological novelty and merges with culture. This marginalizes those who see the Internet as a digital utopia and a means of redeeming society, but also those who demonize the Internet and accuse it of permanently cutting off the cultural roots of humanity" (Csepeli - Prazsák, 2010, 13).

Bertalan Komenczi (2002) on his book on information society listed factors that determine its nature:

- the constant transitional state makes it difficult to include short-term forecasts;

- there is a strong technological determinism in the information society;

- the information society is embedded in the global economy;

- the information society is a network society;

- the information society is a knowledge-based and learning society;

- the information society is a society overwhelmed by information;

- the information society is a new type of mass society;

- differences in the information society are growing and developing the digital divide.

\section{Digital pedagogy in the information society}

In order to develop a framework of a digital pedagogy which will be tested by empirical research, we first need to examine the factors that influence the teaching-learning process in the information society. The following questions must be answered:

\section{Role of external factors in the learning process:}

- How can we overcome the fragmentation and reconcile the activities of the public and corporate sectors? What institutional changes are needed to make digital education a success?

- How can new technology be used in education so that machine operators become machine designers?

- In an ecosystem of incompatible devices and formats over the long term, how can knowledge be stored and passed to the next generations?

- If there is a communication platform which teachers have neither control nor awareness of, how can effective communication between them and students be ensured? 
- Should different areas of life be separated regarding the use of technology? If everyday activities: getting information, communication, navigation, shopping, managing finances, leisure, are all dependent on technology more than education what does the school has to do to catch up?

- To what extent can individual learning paths be taken into account? Who should develop the algorithms needed for them?

\section{The role of internal factors in the learning process:}

- What are the cognitive changes caused by the use of digital content, computers, screens, and networks?

- What are the cultural changes caused by digital literacy?

- What are the changes caused by reading hypertext, which supports a non-linear information reception strategy, especially with the fact that navigating through hyperlinks offers different reading experience as opposed to linear storytelling?

- What are the cognitive changes caused by the new ways of searching for, browsing, and scanning the information?

- If there is constant pressure on humans to communicate online, how can they decide which information is relevant?

- What are the changes caused by virtual and augmented reality used in illustration?

- Do the strong user experience, catharsis, and flow enhance or weaken imprinting?

- How can the urge to create content arise from the passive reception of digital content?

- How can digital content creation develop creativity and learning?

- What are the changes caused by secondary literacy, especially abbreviations, emojis, memes?

- To what extent does crowdsourcing interact with previous creative activities in terms of imprinting?

- To what extent can experience gained in the context of machine learning be used to the process of human learning

- Does the outsourced human memory free up space for creativity or does it lead to digital dementia?

- How can credibility issues be solved in the context of fake news and deep fakes?

- How to overcome information overcrowding?

- What role will libraries play in the process of storing digital curricula?

- Can the gamification based on strong involvement be effectively integrated into the learning process on a global scale?

- What is the role of visuality in maintaining attention? How much of the entertainment content (Netflix and Facebook effect) suppresses educational content?

- How will the Maslow's hierarchy of needs transform and how does it affect learning?

- How can digital-assisted learning be effective without addiction to devices? 


\section{Revolutionizing the teaching. Again?}

Let us start with a citation: "The promise that digital education will revolutionize teaching and learning through, for example, the wide availability of digital learning resources or radically restructured virtual learning experiences, often passes without comment on the problematic social, ethical and epistemic assumptions underpinning such changes. While digital devices have long since become embedded in contemporary life, our social, cultural and particularly our educational institutions are struggling to keep up with the pace of change" (Lewin - Lundie, 2016: 236).

According to Emile Bojesen (2016: 2), "Alongside questions of how digital pedagogy changes how and what we learn, there is a question of how digital pedagogy and the broader context of what is called the 'information age' changes the learner. What are we learning to become? Is our identity prescribed by our technological context or does our context allow us freedoms in inventing ourselves as subjects that other contexts have not?" [...] The technologies we utilize to understand ourselves (written, spoken and digital language, as well as physical activities and visual and oral languages) also become who we are. As such, these technological contexts play an important part in the invention of the subject.

There are those who are skeptical regarding the use of technology. Jeremy Knox (2016: 315) states that "technology cannot directly speed up the process of learning because it is positioned very clearly as external to an exclusively human rhythm. It can speed up access to content and assist in the management of time, but 'learning' itself remains locked in the framework of the bounded human subject”. David Lundie $(2016,280)$ adds, that "Anxieties surrounding the values and purposes of education in contemporary Western society are both masked and exacerbated by the increasing emphasis on the gathering and ranking of data on performance"

\section{Currently dominant methodologies}

But what are the methodologies that determine the context of learning in the information society? In the flipped classroom, the students acquire the knowledge at home, using online curricula, while the lessons are spent in consultation. "Traditional" e-learning is based on the use of a learning framework or management system that supports education, based on rich media and hypertextuality, providing a lot of images and multimedia. Gamification can be used in the classroom, if appropriate. "During the last couple of years, gamification has been a trending topic and a subject to much hype as a means of supporting user engagement and enhancing positive patterns in service use, such as increasing user activity, social interaction, or quality and productivity of actions. These desired use patterns are considered to emerge as a result of positive, intrinsically motivating gameful experiences brought about by game/motivational affordances implemented into a service." (Hamari - Koivisto - Sarsa, 2014:1.) Web 2.0 platforms allow users to interact and collaborate with each other in a social media dialogue as creators and authors of user-generated content, in contrast to websites where users are limited to be mere receivers of the information. As such, Web 2.0 narrows the gap between academic and common knowledge, between formal and informal learning (Molnár - Szúts, 2014). According to András Benedek, the unrestricted access to masses of users through interactive online platforms is a crucial feature. "One of the special dimensions of the transformation going on in education and pedagogy these days, which is perceivable by ICT applications becoming more and more commonly used, is that we strive to apply images more explicitly than ever before" (Benedek, 2019).

Digital storytelling takes advantage of user-generated content and helps teachers overcome some of the obstacles to productively use technology in their classrooms. "At its core, digital storytelling allows [...] users to become creative storytellers through the traditional processes of selecting a topic, conducting research, writing a script, and developing an interesting story" (Bernard, 2008, 222). The result is a combination of multimedia, images, texts, sounds, video clips. It can be stored on a computer or in a cloud and presented in class. 
One of the dominant tendencies in education is the idea of a Massive open online course (MOOC), but can de quantity usher quality? "The term MOOC has been used to describe a diverse set of approaches and rationales for offering largescale online learning experiences. MOOCs have been delivered using both centralized platforms and services including learning management systems (LMSs) and decentralized networks based on aggregations of blog sites and social media feeds. MOOCs have been designed to support university curricula, academic scholarship, community outreach, professional development, and corporate training applications" (Namestovszki et al, 2018). Learning has thus become even more time and space independent and is hosted on the World Wide Web. It is present in users' homes, transportation vehicles and workplaces. The face-to-face discussion with the teacher has been replaced by chat and online discussion with fellow students. Learning has become horizontal and participants can learn not only from the instructor but their peers too.

Today, MOOC as a term can encompass any learning process in which - both the delivery of content, the communication of the actors and the evaluation take place online; - no input filter conditions, or at least no specific input filtering, level measurement; - the organizers expect a large number of participants to design the course, including a number of criteria, such as content availability, learning activities and the evaluation system (Fodorné, 2018). However, the experience with the MOOCs is not always positive. The dropout rate is high, and without supervision, several topics - such as psychology or creative arts - cannot be studied.

\section{Conclusion}

The effective methodology assumes the conscious use of online communication tools and digital media. We are in a specific situation because it has never happened in the history of learning that teachers and students are simultaneously learning how to be effective in a context that is constantly evolving. In the information society, we assume that teachers may not be better armed with information literacy than students. An effective methodology can save them time and energy, as once the most effective methods have been identified, educators can skip the experimental phase.

Effective use of digital pedagogy assumes that the teacher is aware of the dynamics and mechanisms of action of digital media and communication platforms, tools and applications. An effective teacher can distinguish between real and virtual, credible and fake, public and private, including selection and sharing of information and copyright issues. The information literacy that both teachers and students need to possess assumes that the learning process involves not only commenting on information, but also searching for, filtering, evaluating, sharing, developing, revising and protecting it, and it is a horizontal interaction.

Thus, the way students communicate with each other and with their teachers has changed. According to András Benedek, the characteristic patterns of acquiring knowledge are changing: the conceptual distinction between childhood and adulthood is blurring, and formal educational institutions are increasingly being replaced by virtual environments of open education. (Benedek, 2008) However, it should be emphasized that education and especially higher education is filled with best practices and the lack of a holistic methodology.

A good digital education program must meet the following requirements: it should be designed for education, follow pedagogical principles, offers up-to-date, very diverse content, require just as much intellectual effort to ensure continuous use, and use every possible means to deepen students' knowledge, keep their interest, let them experience digital applications. The increasing quality of multimedia educational content is important, but we often tend to forget that a content-centric approach can override an activity-oriented educational practice if the content is not accompanied by appropriate tasks (Ollé, 2013).

Nowadays, children in schools are mastering the skills of writing and reading with digital skills. Members of society who do not possess digital literacy skills to experience disadvantages in almost every area of life. In the context of the information society, the nature of knowledge also changes: it 
becomes practical, immediately applicable and transdisciplinary. All the rituals associated with the phenomenon of learning are reinterpreted. Classroom attendance (time and space constraint), personal consultation (interpersonal communication), master-student relationship (significance of the teacher's personality), note-taking (recording of knowledge), and university civic life (elite awareness) will all be put to new foundations.

\section{Resources}

- Bauman, Zygmunt (2000): Liquid Modernity. Cambridge: Polity Press.

- Benedek, András (2019): Új paradigma az oktatásban - a képek elsődlegessége. Magyar Tudomány 7. 949-960. DOI: 10.1556/2065.180.2019.7.2

- Benedek, András (szerk.) (2013): Digitális pedagógia 2.0. Budapest: Typotex.

- Bojesen, Emile (2016): Inventing the Educational Subject in the 'Information Age'. Stud Philos Educ 35. 267-278. DOI 10.1007/s11217-016-9519-2

- Csepeli, György - Prazsák Gergő (2010): Örök visszatérés. Budapest: Jószöveg múhely.

- Duchon, Jenő - Tóth Péter (szerk.) (2016): Tanítás és tanulás elektronikus környezetben. Budapest: Typotop Kft.

- Fodorné, Tóth Krisztina (2018): E-learning trendek és kérdések. Opus et Educatio, 5. DOI: http://dx.doi.org/10.3311/ope.244

- Hamari, Juho - Jonna Koivisto - Harri Sarsa (2014): Does Gamification Work?-A Literature Review of Empirical Studies on Gamification. HICSS. 14.

- Knox, Jeremy (2016): Posthumanism and the MOOC: opening the subject of digital education. Stud Philos Educ 35. 305-320 DOI 10.1007/s11217-016-9516-5 315

- Komenczi, Bertalan (2002): Információ és társadalom. Eger: EKF Líceum Kiadó.

- Kis-Tóth, Lajos - Lengyelné, Molnár Tünde (2012): Blended Learning in Practice: A Comparative Analysis. In: Open, University Malaysia (eds.) ICI 2012 International Conference on Information: learning unlimited, Kuala Lumpur, Malajzia: Open University Malaysia, 242-247.

- Lévai, Dóra (2013): Pedagógus szerep, pedagógus kompetenciák az információs társadalomban. Ollé János - Papp-Danka Adrienn - Lévai Dóra - Tóth-Mózer Szilvia Virányi Anita (szerk.): Oktatásinformatikai módszerek. Tanítás és tanulás az információs társadalomban. ELTE Eötvös Kiadó, Budapest, 2013. 76-97.

- Lewin, David - Lundie, David (2016): Philosophies of Digital Pedagogy. Stud Philos Educ 35. 235-240 DOI 10.1007/s11217-016-9514-7

- Lundie, David (2016): Authority, Autonomy and Automation: The Irreducibility of Pedagogy to Information Transactions. Stud Philos Educ. 35. 279-291 DOI 10.1007/s11217-016-9517-4 
- Molnár, György - Szúts, Zoltán (2014): Advanced mobile communication and media devices and applications in the base of higher education. Intelligent Systems and Informatics (SISY). 2014 IEEE 12th International Symposium DOI $10.1109 /$ SISY.2014.6923580

- Molnár, György (2016): The Impact of Modern ICT-based Teaching and Learning Methods in Social Media and Networked Environment. In: Milan, Turčáni; Zoltán, Balogh; Michal, Munk; Lubomír, Benko (szerk.): 11th International Scientific Conference on Distance Learning in Applied Informatics. Nyitra. 341-350.

- Namestovski, Žolt - Major, Lenke - Molnár, György - Szúts, Zoltán - Esztelecki, Péter Kőrösi, Gábor (2018): External Motivation, the Key to Success in the MOOCs Framework. Acta Polytechnica Hungarica, Vol. 15, No. 6, 125-142. DOI: 10.12700/APH.15.6.2018.6.7

- Ollé, János (2013): Oktatási módszerek és tanulásszervezés az információs társadalom iskolai gyakorlatában. In. Ollé János - Papp-Danka Adrienn - Lévai Dóra - Tóth-Mózer Szilvia - Virányi Anita (szerk.): Oktatásinformatikai módszerek. Tanítás és tanulás az információs társadalomban. ELTE Eötvös Kiadó, Budapest, 76-97.

- Ollé, János (2013): Pedagógiai kultúra az információs társadalomban, Ollé János Papp-Danka Adrienn - Lévai Dóra - Tóth-Mózer Szilvia - Virányi Anita (szerk.): Oktatásinformatikai módszerek. Tanítás és tanulás az információs társadalomban. ELTE Eötvös Kiadó, Budapest.

- Racskó Réka: Digitális átállás az oktatásban. Iskolakultúra, Veszprém, 2017.

- Robin, Bernard R. (2008): Digital Storytelling: A Powerful Technology Tool for the 21st Century Classroom. Theory Into Practice, 47:3, 220-228. DOI: 10.1080/00405840802153916

- Szúts, Zoltán (2018): Online. Az internetes kommunikáció története, elmélete és jelenségei. Budapest: Wolters Kluwer Kiadó. 